Dorota Pudo

Uniwersytet Jagielloński

\title{
ROLA REFLEKSJI W NAUCZANIU DOROSŁYCH SŁUCHACZY KOMERCYJNYCH KURSÓW JĘZYKOWYCH
}

\author{
The role of reflection in teaching adult students on commercial \\ language courses
}

\begin{abstract}
This article examines various levels of reflection in language learning and teaching, such as reflecting on one's own foreign language production, on the language system in general, on one's learning habits and, in the case of the teacher, on the teaching process. The author hypothesizes that all of these are bound to change some of their characteristics depending on features such as age of the learner and learning context. The article examines reflection in adult students of commercial language courses, trying to point out that all the levels of reflection mentioned are supposed to increase in this group. Age is proved to increase language-focused reflectivity in the subjects, whereas the specific learning context might, for reasons of strong personal motivation, be an asset in encouraging learner reflections on their own learning strategies. These conclusions are nonetheless to be treated with caution, for some specific inhibitors to reflection might appear in this group as well, and further research is needed to confirm this possibility.
\end{abstract}

Keywords: reflection, reflexivity, language teaching, adult learners

Słowa kluczowe: refleksja, refleksyjność, glottodydaktyka, dorośli uczniowie

\section{Wprowadzenie}

Termin refleksja nie jest jednoznaczny. Etymologicznie, pochodzi on od łacińskich słów „reflexio" - odgięcie, od „reflectere, reflectum” - „zgiąć wstecz” lub 
„odbijać". W języku potocznym, oznacza albo czynność namysłu nad czymś, albo wypowiedź bądź myśl będącą efektem tej czynności. Z kolei w filozofii, gdzie refleksja funkcjonuje jako termin naukowy i ma bardziej precyzyjne znaczenie, rozumie się ją jako aktywność poznawczą podmiotu skierowaną na niego samego, na jego własną aktywność a nie na świat zewnętrzny (Tokarski, 1980: 632). W każdym ze swoich znaczeń, pojęcie to zawiera element zwrotności, zwrotu ku czemuś, a nawet pewnej wtórności. Różne ujęcia refleksji, jakie można znaleźć w literaturze glottodydaktycznej, można rozumieć jako różne stopnie tej zwrotności. W każdym z nich podmiot zwraca się, mniej lub bardziej świadomie, ku pewnym aspektom procesu opanowywania języka: ku własnej wypowiedzi (Trevise, 1996: 3), ku samemu językowi (Krashen, 1982: 10), ku własnym procesom poznawczym odpowiedzialnym za opanowywanie języka (Myczko, 2004: 24) czy, w przypadku nauczyciela, ku (własnym) czynnościom organizującym proces opanowywania języka u innych podmiotów (Michońska-Stadnik, 2013: 22-23) (przegląd różnych stanowisk dotyczących refleksji w glottodydaktyce, skoncentrowanych głównie na zwrotnych ujęciach języka, por. Trevise, 1996). Celem tego artykułu jest analiza każdego z tych ujęć na podstawie istniejącej literatury teoretycznej i badawczej, aby następnie odnieść wynik tych analiz do specyficznej sytuacji edukacyjnej, jaką jest kurs komercyjny dla dorosłych słuchaczy.

\section{Cztery obszary refleksji glottodydaktycznej}

\subsection{Refleksja nad własną wypowiedzią}

Często zdarza się, że mówiący podmiot - nawet, kiedy mówi w języku ojczystym - w jakiś sposób zwraca się ku własnej wypowiedzi, komentując ją, poprawiając, objaśniając itp. Trevise (1996: 3), omawiając różne rodzaje refleksyjności w uczeniu się języków obcych, określa ten jej poziom jako „le métalinguistique" - to, co metajęzykowe, i widzi w nim pewien, niekoniecznie świadomy, dystans mówiącego do własnej wypowiedzi. Ponadto, niekiedy to, co chcemy powiedzieć, jest trudne do wyrażenia i przez dłuższą chwilę musimy szukać właściwych słów; wówczas język traci swą transparentność i refleksyjny zwrot ku jego formie staje się konieczny. Zdaniem niektórych autorów, szeroko pojęta refleksyjność jest integralną częścią wszelkiej komunikacji. Jak piszą Vasseur i Arditty (1996: 7):

Interakcja implikuje refleksyjność. Niezależnie od tego, czy mówi czy nie, odbiorca (który jest także nadawcą) odsyła nadawcy (który jest także odbiorcą) jego własne słowa. Samą swoją obecnością (...) determinuje ciągłe przemiesz- 
czenia nadawcy, który, w celu poprawy jakości interakcji, potrzebuje postawić się na miejscu drugiego. Przez swą podwójną funkcję, każdy z interlokutorów jest podwojeniem i zwierciadłem drugiego. W ten sposób powstaje gra odbić, refleksów, refleksji, które tworzą i artykułują wspólny dyskurs. (tłum. własne)

W sytuacji komunikacji egzolingwalnej z pewnością częściej można zaobserwować refleksyjne wahania co do leksykalnej lub gramatycznej formy wypowiedzi, wyrażone werbalnie lub niewerbalnie. Glottodydaktycy wielokrotnie badali ślady takiej refleksyjnej działalności, obecne w komunikacji. Wyróżniali wiele rodzajów refleksyjnych interwencji we własną wypowiedź, np. sądy o gramatycznej poprawności, manipulacje i formułowanie reguł (por. Vasseur i Arditty, 1996: 4). Niektórzy badacze zauważają, że to sama sytuacja dydaktyczna może w dużej mierze wywoływać taką aktywność, np. Berthoud (1982) przypisuje m.in. obecności nauczyciela tendencję podmiotu do odwoływania się do reguł normatywnych. Różne też mogą być stopnie świadomości przy aktywności tego typu. We francuskojęzycznej literaturze przedmiotu mówi się o aktywności metalingwistycznej, kiedy podmiot w pełni świadomie pochyla się nad tym, co powiedział, i epilingwistycznej (termin wprowadzony przez Culioli, 1968), gdy koryguje własną wypowiedź podświadomie (por. Berthoud, 1982; Huot i Schmidt, 1996).

\subsection{Refleksyjne opisywanie języka}

Innym rodzajem refleksyjności, wciąż dotyczącym samego języka, szczególnie obcego (lecz ma to miejsce także podczas zinstytucjonalizowanego nauczania języka ojczystego), jest skupienie się na opanowywanym czy studiowanym języku poza sytuacją komunikacji; chodzi tutaj, na przykład, o typową „lekcję gramatyki”, której przedmiotem jest formalna strona języka, poznawana właśnie poprzez refleksję, a nie przyswajana „przypadkowo” w toku komunikacji. Krashen (1982: 10) wyraźnie rozdziela dwa sposoby opanowywania języka, nabywanie (acquisition) i uczenie się (learning). To pierwsze definiuje jako podświadomy proces zorientowany na komunikację i sens, odpowiadający uczeniu się implicite, naturalnemu i nieformalnemu, prowadzący do intuicyjnej znajomości języka obcego, podczas gdy to drugie jest procesem świadomym, zorientowanym na formę, opartym na wiedzy explicite i prowadzącym do świadomej, a więc refleksyjnej znajomości języka obcego, jego reguł gramatycznych i do umiejętności werbalizacji tych reguł. Oczywiście, ten podział jest uproszczony: naturalnemu nabywaniu języka towarzyszy często refleksja, a instytucjonalna nauka korzysta też z uczenia się implicite. Nawet dzieci uczące się języka ojczystego nie robią tego w spo- 
sób całkowicie bezrefleksyjny: dorośli opiekunowie nie dają im wprawdzie lekcji gramatyki na każdym kroku, jednak poprawiają je i udzielają im wyjaśnień. Czasami zdarza się także, że samo dziecko jest zaskoczone jakąś formą lub w ogóle nie potrafi jej utworzyć: są to u niego momenty refleksji. Jednak podział Krashena posiada pewną heurystyczną użyteczność, stąd różne jego warianty są w literaturze bardzo powszechne (por. zestawienie terminologiczne w Huot i Schmidt, 1996: 3-5).

\subsection{Refleksja ucznia nad własnym uczeniem się}

Oprócz zwrotnego skupienia się podmiotu na samym języku, w glottodydaktyce termin „refleksja” stosuje się, by opisać zdolność ucznia do zwrócenia się ku własnym procesom poznawczym. Każdy namysł nad własnym uczeniem się potencjalnie skutkuje jego ulepszeniem, np. przez lepszą organizację czasu nauki czy wdrożenie skuteczniejszych technik przyswajania języka. Z tymi działaniami wiąże się pojęcie strategii uczenia się, rozumiane jako wybór konkretnych działań prowadzących do opanowania pewnego materiału czy sprawności językowej, docelowo w sposób najskuteczniejszy dla danej jednostki. Refleksja potrzebna jest właśnie do tego, żeby ustalić, która z technik sprawdzi się dla konkretnej osoby czy też pewnego typu materiału. W tym rozumieniu, refleksja często jest też analizowana w świetle pojęcia autonomii ucznia, której jest jednym z przejawów, rozumianej jako wzięcie przez ucznia odpowiedzialności za własne uczenie się, co trudno sobie wyobrazić przy postawie bezrefleksyjnej, która nie pozwala na zakwestionowanie skuteczności własnych działań. Tymczasem wydaje się, że duża liczba uczących się języków obcych woli przerzucać odpowiedzialność na nauczyciela i nie poświęca cennego czasu na rozważania o tym, w jaki sposób i jak skutecznie uczą się języka.

\subsection{Refleksja nauczyciela nad procesem dydaktycznym}

Wreszcie rozumienie refleksyjności na tym samym poziomie można odnieść nie do ucznia, a do nauczyciela, który z założenia, ujmując w akcie refleksji własne działania, jednocześnie widzi w nim całość procesu dydaktycznego. O nauczycielu, niekoniecznie języków obcych, coraz częściej mówi się jako o refleksyjnym praktyku. Na podstawie różnych definicji tego pojęcia znajdujących się w literaturze Silcock podaje następujący opis refleksyjnego praktyka (1994: 281):

Refleksyjni praktycy mogą być tymi, którzy wykorzystują osobistą wiedzę, wyrażoną (...) przez metaforę, opowieść, autobiografię lub dyskurs kooperatywny. Mogą mieć własny repertuar umiejętności refleksyjnych lub podnosić 
swoje umiejętności poprzez analizę w kierunku mistrzostwa albo, bardziej akademicko, rozważać praktykę w świetle tradycyjnych wartości, coraz lepiej rozumiejąc różne zjawiska dzięki prowadzonym badaniom. W każdym z tych przypadków, mamy do czynienia z różnymi rodzajami refleksji, w zależności od doświadczeń i celów danego praktyka. (tłum. własne)

Podobnie jak uczący się, nauczyciel może potencjalnie wpłynąć na adekwatność i skuteczność swoich działań: w tym celu musi poddać je wszechstronnej analizie. Samej refleksyjności można się nauczyć, czyniąc ją wyćwiczonym nawykiem, stąd często proponuje się przyszłym nauczycielom w ramach ich kształcenia zawodowego kursy refleksyjnego nauczania czy myślenia, które, zdaniem projektujących i wdrażających je badaczy, odznaczają się dużą skutecznością (por. Minott, 2011). Mają one zapobiec choćby takim nierozwojowym postawom, jak bezrefleksyjne powielanie doświadczeń z własnej edukacji, z pominięciem wszelkich nowych rozwiązań dydaktycznych poznanych na studiach, co zdarza się nauczycielom (por. Dassier, 2001).

\section{Refleksja u dorosłych słuchaczy kursów komercyjnych}

\subsection{Charakterystyka omawianej grupy}

Jak widać z tej pobieżnej prezentacji zjawiska, refleksja we wszystkich jej znaczeniach jest bardzo ważnym elementem procesu uczenia się i nauczania języków obcych, obecnym od dawna w literaturze glottodydaktycznej, stąd zasadne wydaje się zadanie sobie pytania, jakie będą różnice w refleksyjności w zależności od charakterystyki odbiorców. Tutaj skupimy się na jednej, bardzo szczególnej grupie uczniów języków obcych, której liczba i znaczenie dynamicznie wzrastają, a wciąż rzadko bywa wyodrębniana i badana właśnie w tym kształcie przez glottodydaktyków: dorośli słuchacze komercyjnych kursów językowych. Te dwa wyróżniki - wiek i rodzaj procesu edukacyjnego - zdają się wystarczająco definiować i wyodrębniać tę grupę, a ich potencjalny wpływ na refleksyjność zdaje się być znaczący. Zdolność do refleksji jest jednym z teoretycznych wyznaczników dorosłości (por. definicję dorosłego w Holster, 1986), mocno kontrastującym ze spontanicznością dziecka. Ponadto, jeśli chodzi o samo opanowywanie języków, dziecko i dorosły są paradygmatycznymi wzorcami dwóch wcześniej opisanych stylów uczenia się: naturalnego, implicite i refleksyjnego, explicite; stąd można się spodziewać, że wiek wpłynie na te poziomy refleksyjności, które mają za przedmiot sam język. Z kolei, jeśli chodzi o wybór komercyjnych kursów, można postawić hipotezę, że będzie on sprzyjał refleksyjności skierowanej na własny 
proces uczenia się, ze względu na specyficzne elementy motywacyjne. Przyjrzyjmy się zatem, jak, w tej konkretnej grupie odbiorców, wygląda refleksyjność w jej różnych wyodrębnionych wcześniej znaczeniach.

\subsection{Refleksja nad własną wypowiedzią u dorosłych słuchaczy komercyjnych kursów językowych}

Każdy użytkownik języka, obcego czy ojczystego, niezależnie od wieku i stopnia zaawansowania, czasami refleksyjnie zwraca się ku własnej wypowiedzi językowej, żeby ją ulepszyć, poprawić jej formę bądź uczynić ją bardziej zrozumiałą dla rozmówcy. Badacze wyróżniają bardziej i mniej świadome, refleksyjne organizowanie własnej wypowiedzi (por. Vasseur i Arditty, 1996: 6; Trevise 1996: 12). O ile pauza w wypowiedzi, wahanie czy wypełniacz parawerbalny mogą wymknąć się mówiącemu nieświadomie, może on "szukać słowa", nie zdając sobie nawet sprawy, że właśnie to robi, o tyle bardziej rozbudowane komunikaty typu „chciałem przez to powiedzieć, że...”, „miałem na myśli..." albo „jak się to mówi?”, zdają się świadczyć o świadomej refleksji metajęzykowej podmiotu. Oczywiście, granica między tymi dwiema grupami jest bardzo płynna, zwłaszcza że nie da się precyzyjnie zbadać stopnia świadomości, z jaką ktoś w danym momencie dokonuje refleksji nad swoją wypowiedzią: zwykłą pauzę może wypełniać całkiem świadoma refleksja np. nad formą czasownika, której należy użyć, a wtrącenia w stylu „to znaczy”, „chciałem powiedzieć" u niektórych osób są produkowane nawykowo, jako rodzaj tiku językowego i nie świadczą o żadnej świadomej refleksji. Metajęzykowe interwencje dorosłych zdają się być bardziej świadome, i to mimo faktu, że z natury rzeczy są oni bardziej kompetentnymi użytkownikami przynajmniej jednego języka niż dzieci, będące wciąż w trakcie opanowywania go. Dzieci często mylą się beztrosko, przerzucając większość ciężaru procesu tworzenia znaczenia na zawsze życzliwego dorosłego rozmówcę, który robi wszystko, żeby zrozumieć i w razie potrzeby naprawić komunikat, podając dziecku poprawną formę i sugerując, żeby ją zapamiętało i w przyszłości użyło. Dorośli natomiast, nawet mówiąc w obcym języku, często starają się, żeby ich wypowiedź była od razu maksymalnie poprawna i zrozumiała, żeby nie utrudniać drugiej stronie interakcji (względy etyczne, szacunek do rozmówcy), żeby się nie ośmieszyć (dbałość o własne ego w komunikacji), żeby nie wydać się nieprofesjonalnym (obrazy siebie, autoprezentacja) itp. Na lekcjach języka obcego taka zwiększona refleksyjna kontrola nad komunikatem przejawia się częstokroć długim namysłem przed wypowiedzią, względnie nawet potrzebą wcześniejszego zapisania jej, licznymi pauzami, wahaniami, a także autopoprawkami w trakcie wypowiedzi, wreszcie częstym wyrażaniem własnej nie- 
wiedzy przez komentarze („nie wiem, jak jest...”) lub pytania do nauczyciela. Taka refleksyjność, stosunkowo częsta u dorosłych słuchaczy kursów komercyjnych, pozwala im lepiej wykorzystać czas kursu, a w szczególności przestrzeń własnej wypowiedzi, gdyż dopytują o informacje, poznają nowe słowa, utrwalają poprawne formy odmiany itp. Odbywa się to jednak kosztem płynności wypowiedzi, a niekiedy także komunikatywności, gdyż wypowiedź przerwana trzema pytaniami o formę czasownika jest ostatecznie mniej zrozumiała niż ta sama wypowiedź z trzema błędami w odmianie.

Z drugiej strony, badacze zauważają, że refleksyjne interwencje we własny dyskurs, w szczególności w komunikacji egzolingwalnej, przebiegają na różnych poziomach, z których ten czysto poprawnościowy jest jednym z najbardziej podstawowych. Bouchard i de Nuchèze (1987, cyt. za Vasseur i Arditty, 1996) wyróżniają następujące poziomy takich interwencji: odniesione do kodu językowego (activités métalinguistiques), do organizacji dyskursu (métadiscursives), do fizycznych warunków produkcji i odbioru przekazu (métalocutoires), do dialogicznej organizacji zdarzenia komunikacyjnego (métacommunicatives), lub do regulacji tego zdarzenia w wymiarze ściśle językowym (méta-interactionnelles). Możemy zaryzykować hipotezę, że osoby dorosłe będą starały się kontrolować nie tylko poprawność gramatyczną lub adekwatność leksykalną własnej wypowiedzi, ale także będą dbały o jej organizację, warunki dialogu itp. Większą rolę będą zatem odgrywały w tej grupie wszystkie te elementy, które charakteryzują się zarówno większą świadomością własnych wypowiedzi i sytuacji komunikacyjnej, jak i większą złożonością, a więc koniecznością jednoczesnego kontrolowania większej ilości czynników.

\subsection{Refleksyjne opisywanie języka na kursach komercyjnych dla dorosłych}

Równie interesująca jest refleksyjność rozumiana w kontekście metajęzykowego opisu poszczególnych podsystemów języka. Dzisiaj wciąż aktualne jest podejście komunikacyjne, które nie przywiązuje do wyjaśnień gramatycznych wielkiej wagi, a używanie gramatycznego metajęzyka często uważa za niepotrzebny balast. Mimo to, w powszechnej edukacji zwłaszcza początkujący nauczyciele chętnie wprowadzają długie bezpośrednie instrukcje gramatyczne, a ich lekcje poświęcone są w dużej części wykładaniu jakiegoś gramatycznego zjawiska, które jest przez nich prezentowane, tłumaczone, a następnie ćwiczone na wielu przykładach, przez co nie starcza czasu na ćwiczenie innych sprawności (Michońska-Stadnik, 2013: 58). Co ciekawe, lekcje takie prowadzi się na każdym etapie edukacji, począwszy od szkoły podstawowej, choć często zakłada się, że dzieci łatwiej przyswajają język na drodze nabywania, implicite, zbliżonej do opanowywania języka ojczystego, a doro- 
śli na drodze świadomego, refleksyjnego uczenia się. Z badań, a konkretnie z porównania trzech studiów przypadku (Huot i Schmidt, 1996) wynika, że wiek nie jest jedynym czynnikiem odpowiedzialnym za skłonność do refleksji nad formalną stroną języka obcego w trakcie opanowywania go: autorzy porównują studia dotyczące dwojga dorosłych (jeden z nich to japoński malarz, a drugi językoznawca, jeden z autorów artykułu) i siedmioletniej dziewczynki. Okazuje się, że z tej trójki to malarz jest najmniej refleksyjny w omawianym sensie, robi też znikome postępy jeśli chodzi o gramatykę, skupiając się wyłącznie na zrozumieniu i jasnym przekazaniu własnego komunikatu. Dziewczynka okazuje się bardziej dociekliwa, wypytując o formę wszędzie tam, gdzie jej nieznajomość przeszkadza jej w odczytaniu treści komunikatu. Najbardziej refleksyjny okazał się językoznawca, który uczył się języka jako systemu, w dużej mierze poprzez wyjaśnienia gramatyczne. Czynnikami, które zdaniem autorów mogły zaważyć na podejściu uczestników badań do wyjaśnień gramatycznych była ilość znanych już języków obcych (językoznawca znał kilka, dziewczynka i malarz uczyli się pierwszego języka obcego) i osobowość (dziewczynka i malarz byli towarzyskimi ekstrawertykami nastawionymi na komunikację, językoznawca był refleksyjnym i logicznym introwertykiem).

Na komercyjnych kursach językowych, podobnie jak w szkole powszechnej, można spotkać się z tradycyjnymi lekcjami gramatyki, choć z pewnością jest to rzadsze, bo jednym z wyróżników szkół językowych oferujących tego typu szkolenia jest innowacyjna dydaktyka, do której się chętnie odwołują, choć w praktyce większość pracuje eklektycznie. Tym niemniej faktem jest, że wielu dorosłych słuchaczy, nieświadomych stosowania przez daną szkołę takich czy innych technik dydaktycznych lub niemających wpływu na wybór oferty, domaga się na kursie takiego nauczania, jakie sami znają ze szkoły i uważają za skuteczne, zwłaszcza jeśli dzięki niemu opanowali już jeden język obcy w stopniu, który wydaje im się wystarczający. Większość dorosłych była uczona języka w sposób bardziej refleksyjny i opisowy, niż próbuje się to robić obecnie, po triumfie podejścia komunikacyjnego, stąd wielu z nich domaga się od lektorów systematycznych wyjaśnień czy tabelek. Turula (2004) przytacza przykład grupy dorosłych, którzy od lektora stosującego techniki autonomizujące, w szczególności samodzielne indukowanie reguł gramatycznych, zniecierpliwiona zażądała narysowania „tabelki z czasami". Autorka takie zachowanie uznała za nieautonomiczne i doszła do wniosku, że jedynym wyjściem jest autorytatywne nauczanie takich osób skuteczniejszych i bardziej autonomicznych technik uczenia się języka. Można się zastanawiać, czy to podejście nie jest jednak odrobinę jednostronne i nie preferuje zbyt jednoznacznie określonych - komunikacyjnych i konstruktywistycznych - podejść do nauki języka. Gdyby jednak uznać, że różne 
jednostki skutecznie uczą się w różny sposób, samodzielnie odkrywając prawidła gramatyczne lub ucząc się ich z gotowych tabelek, można by dojść do wniosku, że świadomość własnych potrzeb edukacyjnych, jaką wykazali się uczniowie, świadczy właśnie o ich pewnej dojrzałości.

\subsection{Refleksja dorosłego ucznia nad własnym uczeniem się}

Ta kwestia prowadzi nas do kolejnego zagadnienia, jakim jest zdolność dorosłych uczestników komercyjnych kursów do refleksji nad własnym procesem uczenia się, uznawanej za jeden z niezbędnych elementów autonomii ucznia (por. Kierczak i Sitko, 2004). Można by podejrzewać, że zdolność ta będzie większa niż u młodzieży szkolnej, nie tylko z powodu wieku, ale także z racji spodziewanej w takich warunkach autonomicznej motywacji. W odróżnieniu od obowiązkowej nauki szkolnej, decyzja o podjęciu nauki na kursie językowym często jest dobrowolna, choć wyjątkiem bywają kursy zamówione przez korporacje, w których udział jest niekiedy wymuszony przez pracodawcę jako warunek awansu lub w ogóle dalszego zatrudnienia. Nawet jednak w takiej sytuacji, dorosły jasno zdaje sobie sprawę z korzyści, w tym wypadku zawodowych, jakie daje opanowanie języka, podczas gdy uczniowie szkół powszechnych różnych szczebli nie zawsze widzą dalekosiężne przełożenie podejmowanych wysiłków na szanse w późniejszym życiu. Posiadanie silnej motywacji do nauki niewątpliwie sprzyja inwestowaniu dodatkowego czasu i wysiłku, jakiego wymaga refleksja nad własnym uczeniem. Można jednak zaobserwować, że bez sugestii ze strony nauczyciela niewielu uczestników będzie skłonnych przypuszczać, że ich uczenie się, wyćwiczone przez lata nauki szkolnej, może wymagać przemyślenia lub ulepszenia; wielu traktuje stare, sprawdzone techniki (przepisywanie słówek do zeszytu i uczenie się ich na pamięć) jako jedyny możliwy sposób na indywidualną naukę języka obcego. Autorefleksję niejako wymuszają arkusze oceny kursu, które placówki zazwyczaj rozdają uczestnikom pod koniec cyklu kształcenia (semestru lub roku), a które oprócz oceny kursu zawierają też niekiedy rubrykę samooceny, na której uczestnik ma określić stopień zadowolenia z własnych postępów, z przygotowania do zajęć, z odrabiania prac domowych itp. Z naszych własnych doświadczeń wynika, że uczestnicy często stawiają najniższe noty właśnie w tej części, wysoko oceniając kurs i lektora, a nisko własny wkład pracy. Tak ogólna refleksja nie pozwala jednak zdiagnozować przyczyn niedostatecznego zaangażowania czy zbyt niskiej skuteczności podejmowanych działań uczeniowych. Zakładamy, że lektor może próbować nieco zwiększyć autorefleksję słuchaczy, zachęcając do niej czy nawet kierując nią poprzez zadawanie odpowiednich pytań o strategie 
czy techniki, stosowane przez uczniów podczas pracy własnej, o ich efektywność oraz o znajomość alternatywnych technik lub prosząc o próbę twórczego wymyślenia kilku. Jeśli podczas takiego seansu słuchacze wymyślą coś, co im się rzeczywiście przysłuży w przyszłości, będzie to dla nich samo w sobie wielkim zyskiem, a być może także zachęci do dalszego, autonomicznego podejmowania refleksji o własnym uczeniu. Inną, nieco subtelniejszą metodą zachęcenia dorosłych do refleksji, może być zadanie im nietypowej pracy domowej. Taka praktyka naturalnie wywołuje pytania typu „po co to? Co ma mi to dać? Dlaczego nauczyciel uważa to za sensowne zadanie?...", które mogą prowadzić także do autorefleksji, a jeśli będą zadawane częściej, nawet do wyrobienia pewnego refleksyjnego nawyku, który w przyszłości może przełożyć się na każdy, nawet typowy rodzaj działań uczeniowych.

\subsection{Refleksja lektora komercyjnego kursu nad procesem dydaktycznym}

Jeśli zaś chodzi o ostatni obszar glottodydaktycznej refleksji, który wyróżniliśmy na początku, czyli „refleksyjną praktykę” nauczyciela, wydaje się, że w porównaniu z pracą w szkole powszechnej, rola lektora na komercyjnych kursach dla dorosłych szczególnie stymuluje zdolność do autorefleksji. Po pierwsze dlatego, że nauczyciel ma tutaj z definicji większą swobodę, nie ogranicza go instytucjonalnie narzucona podstawa programowa, nie musi realizować podręcznika w założonym z góry tempie, jest w dużej mierze projektantem swojego kursu. Po drugie, w większym stopniu musi on uwzględniać informację zwrotną ze strony uczestników kursu niż nauczyciel w szkole, gdzie uczniowie często nie mają odwagi krytykować jego poczynań, uważają je za oczywiste lub, jeśli już to czynią, nie potrafią uzasadnić swojego stanowiska i nauczycielowi łatwo jest pomyśleć, że w istocie nie mają nic ciekawego do powiedzenia, tylko krytykują, bo „nie chce im się uczyć” (por. wyniki ankiet Choy i Oo, 2012, przeprowadzonych z malezyjskimi nauczycielami). Na komercyjnym kursie, uczestnicy bardziej otwarcie wyrażają swoje konkretne potrzeby edukacyjne i preferencje, negocjują konkretne elementy treści kursowych czy też techniki dydaktyczne, co ułatwia lektorowi autorefleksję, tym bardziej że uwzględnianie oczekiwań słuchaczy w naturalny sposób wpisuje się w jego pracę, a od ich zadowolenia w dużej mierze zależy, czy w kolejnym cyklu lektor będzie mógł kontynuować kurs, a tym samym, czy dostanie kolejne godziny, za którymi idzie wynagrodzenie. Oczywiście, w takim podejściu pułapką jest chęć dogodzenia wszystkim i uleganie żądaniom uczestników kursu, jeśli ma się to wiązać z obniżeniem poziomu kursu lub jeżeli cele słuchaczy są sprzeczne z celami instytucji zamawiającej kurs, np. korporacji, która ich zatrudnia. Dlatego bardzo istotne jest, żeby lektor 
rzeczywiście dokonywał refleksji, a nie zadowalał się mechanicznym spełnianiem próśb czy żądań słuchaczy.

\section{Podsumowanie}

Podsumowując, można powiedzieć, że każdy wymiar refleksji wydaje się być w pewnym stopniu specyficzny dla grupy, jaką są dorośli słuchacze komercyjnych kursów językowych. Generalnie można się spodziewać, że we wszystkich wymiarach będzie ona głębsza i częstsza niż w przypadku młodzieży szkolnej, co wynika po części z samego wieku, doświadczenia, większej dojrzałości tego typu uczniów, a także bardziej autonomicznej motywacji; trzeba jednak uwzględnić także specyficzne przeszkody, które mogą utrudniać refleksję w tej właśnie grupie.

Jeśli chodzi o refleksję rozumianą jako zwrot ku własnej wypowiedzi obcojęzycznej, udało nam się zaobserwować, że występuje ona rzeczywiście bardzo często u dorosłych, lecz nie zawsze jest to korzystne z punktu widzenia opanowywania języka, gdyż wiąże się z przesadnym perfekcjonizmem i tendencją do hiperpoprawności. Rolą nauczyciela może zatem być zachęcenie słuchaczy do podejmowania większego ryzyka komunikacyjnego, które pozwoli im nawiązać zrozumiały, choć niekoniecznie od razu stuprocentowo poprawny kontakt z rozmówcą; refleksja nad ewentualnymi popełnionymi błędami może być następnym krokiem.

Refleksyjny zwrot ku systemowi językowemu jest często narzucany uczącym się języka na różnych szczeblach edukacji, w tym na kursach komercyjnych dla dorosłych. Ci ostatni wydają się być stosunkowo dobrze przygotowani do tego typu pracy, gdyż wielu z nich uczyło się pierwszego języka obcego, zanim podejście komunikacyjne stało się popularne. Tę umiejętność można wykorzystać dydaktycznie, lecz niekiedy staje się ona przeszkodą, gdy nawyk studiowania języka jako abstrakcyjnego systemu utrudnia pracę nad kształceniem kompetencji komunikacyjnej.

Dorośli zdają się być, z racji swojej dojrzałości i większej ilości doświadczeń edukacyjnych, w lepszej sytuacji niż młodzież jeśli chodzi o refleksję nad własnym procesem uczenia się. Przeszkodą może być tutaj rutyna i brak krytycznego spojrzenia na strategie pracy wyniesione z poprzednich etapów edukacyjnych; stąd rolą nauczyciela jest rozwijanie, poprzez specjalne zadania lub rozmowy, autorefleksyjnego potencjału.

Wydaje się wreszcie prawdopodobne, że praca na komercyjnym kursie dla dorosłych sprzyja refleksyjnej praktyce nauczyciela czy też lektora: ma on większą swobodę działania niż w placówce publicznej, częściej otrzymuje informacje zwrotne, których jakość jest zwykle wyższa niż w przypadku szkół niższych 
szczebli. Pułapką jest tutaj pokusa zbyt dosłownego uwzględniania ewentualnych postulatów uczących się, potencjalnie ze szkodą dla jakości nauczania.

Aby zweryfikować wszystkie te wnioski, warto byłoby przeprowadzić badania empiryczne, ankietowe lub obserwacyjne, dążące do ustalenia, czy rzeczywiście dorośli słuchacze komercyjnych kursów językowych wykazują się większą refleksyjnością, jak sugeruje teoria.

\section{BIBLIOGRAFIA}

Berthoud, A. C. 1982. „La relative fiabilité du discours métalinguistique des apprenants”. Encrages, Enseignement, Recherche: théories et pratiques 8/9: 139-142.

Bouchard, R., de Nuchèze, V. 1987. „Formulations métalangagières et situations exolingues" (w:) S'approprier une langue étrangère (red. H. Blanc, M. Le Douaron, D. Véronique), Paryż: Didier Erudition: 55-62.

Choy S. Ch., Oo P. S. 2012. „Reflective thinking and teaching practices: A precursor for incorporating critical thinking into the classroom?". International Journal of Instruction 5(1): 167-182.

Culioli, A. 1968. „La formalisation en linguistique”. Cahiers pour l'analyse 9: 106-117.

Dassier, J.-L. P. 2001. „Rôles de la communication et de la grammaire pour les novices du français langue étrangère". The French Review 74(4): 686-697.

Holster, J. 1986. Student Autonomy in Adult Classes, Manchester Monographs 05/86.

Huot D., Schmidt R. 1996, „Conscience et activité métalinguistique. Quelques points de rencontre". Acquisition et interaction en langue étrangère 8. http://aile.revues. org/1237 DW 24.07.2013.

Kierczak A. W., Sitko A. 2004. „Autonomia ucznia a nauczanie języka specjalistycznego, czyli czy wprowadzać autonomię na lektoratach?" (w:) Autonomia w nauce języka obcego (red. M. Pawlak), Poznań-Kalisz: UAM: 149-159.

Krashen, S. D. 1982. Principles and Practice in Second Language Acquisition. Oxford: Pergamon Press.

Michońska-Stadnik, A. 2013. Teoretyczne i praktyczne podstawy weryfikacji wybranych teorii subiektywnych w kształceniu nauczycieli języków obcych. Wrocław: Wydawnictwo Uniwersytetu Wrocławskiego.

Minott, M. A. 2011. „The impact of a course in reflective teaching on student teachers at a local university college". Canadian Journal of Education 34(2): 131-147. http://ojs.vre.upei.ca/index.php/cje-rce/article/view/530 DW 24.07.2013.

Myczko, K. 2004. „Kognitywna teoria uczenia się i rozwijanie autonomii ucznia w dydaktyce języków obcych" (w:) Autonomia w nauce języka obcego (red. M. Pawlak), Poznań-Kalisz: UAM: 19-30.

Silcock, P. 1994. „The Process of Reflective Teaching”. British Journal of Educational Studies 42(3): 273-285. http://www.jstor.org/stable/3121886 DW 15.07.2013.

Tokarski, J. (red.) 1980. Słownik wyrazów obcych. Warszawa: PWN.

Trevise, A. 1996 „Réflexion, réflexivité et acquisition des langues”. Acquisition et interaction en langue étrangère 8, http://aile.revues.org/1223 DW 05.06.2013. 
Rola refleksji w nauczaniu dorosłych słuchaczy komercyjnych kursów językowych

Turula, A. 2004. „Czy warto siać? - autonomia na kursach językowych dla dorosłych” (w:) Autonomia w nauce języka obcego (red. M. Pawlak), Poznań-Kalisz: UAM: 285-289.

Vasseur, M.-T., Arditty, J. 1996. „Les activités réflexives en situation de communication exolingue: réflexions sur quinze ans de recherche". Acquisition et interaction en langue étrangère 8, http://aile.revues.org/1245 DW 24.07.2013. 